\title{
Editorial commentary: a journey towards least invasive thoracic surgery?
}

\author{
Jean H. T. Daemen^, Yvonne L. J. Vissers, Karel W. E. Hulsewé, Erik R. de Loos \\ Division of General Thoracic Surgery, Department of Surgery, Zuyderland Medical Center, Heerlen, The Netherlands \\ Correspondence to: Erik R. de Loos. Division of General Thoracic Surgery, Department of Surgery, Zuyderland Medical Center, Henri Dunantstraat 5 , \\ 6419PC, Heerlen, The Netherlands. Email: e.deloos@zuyderland.nl. \\ Comment on: Chen J, Ang KL, Wang C, et al. Minimally invasive carinal reconstruction using bronchial flap and omental flap reinforcement. Ann \\ Thorac Surg 2021;29;S0003-4975(21)01088-2. [Epub ahead of print]. doi: 10.1016/j.athoracsur.2021.06.014.
}

Submitted Sep 16, 2021. Accepted for publication Sep 30, 2021.

doi: 10.21037/tlcr-21-766

View this article at: https://dx.doi.org/10.21037/tlcr-21-766

In a recent issue of the Ann Thorc Surg, Chen and colleagues report on a case of a young female patient suffering from a distal tracheal adenoid cystic carcinoma, affecting the carinal aspect of both bronchi. Following only partial response to neoadjuvant therapy, they performed a carinal resection and reconstruction with bronchial flap, and omental reinforcement using a minimally invasive approach (1). Their approach included both laparoscopy and multiportal video-assisted thoracoscopy (VATS), aiming to reduce surgical trauma and optimizing patient's outcome.

Reports on the use of a VATS-approach for tracheal and carinal tumors are limited, probably due to the low incidence of these tumors as well as technical considerations. Despite the multiple advantages that have been reported for VATS for parenchymal resections, including less pain, fewer in-hospital complications, as well as shorter chest tube duration and hospitalization $(2,3)$, an open approach remains the gold standard for these type of resections. The technical challenges associated with VATS for a complex procedure, as described by Chen and colleagues (1), underline that performing such procedures is only feasible for very experienced, high-volume centers where adequate exposure in numbers allows surgeons to overcome their associated learning curve. Therefore, safe implementation of such technically highly demanding procedures is likely not feasible in most Western centers.

Despite the higher upfront costs of a thoracoscopic approach as compared to thoracotomy (4), known advantages of VATS for parenchymal resections include quicker recovery (3) and improved survival (5). Due to the relative rarity of VATS carinal resections, it is however unknown whether this also applies for complex procedures as described by Chen and colleagues (1).

Using prophylactic omental flap reinforcement, Chen and colleagues aimed to minimize the risk of complications associated with the airway reconstruction through promotion of healing and neovascularization (1). Especially after neoadjuvant therapy there is a risk for failure of healing of the anastomosis. In the literature success rates up to $86 \%$ have been reported for omental reinforcement after airway resection which seems superior to the use of muscle flaps (6). Although omentoplasty is accordingly deemed as highly effective in the management of complex cardiothoracic surgical problems (6), most results emerge from low-level evidence reports. Therefore, the indications for its use are largely based on the surgeon's experience, although neoadjuvant therapy often is reason to include some form of tissue reinforcement as described in the case report.

One of the novelties of the presented case is the employed complete minimally invasive approach, as well as the use of a bronchial flap which is not considered as standard. The next step towards least invasive surgery would be to perform uniportal VATS combined with singleincision laparoscopy (SILS). In general, uniportal VATS is associated with reduced complication rates, as well as

$\wedge$ ORCID: 0000-0002-4878-3951. 
reduced duration of postoperative drainage and length of hospitalization compared to its multiport alternative (7). Consequently, this could ensure further optimization of the already good post-operative outcome described by Chen and colleagues. Yet, in contrast, SILS does not seem to offer any objective remarkable advantages over conventional laparoscopy, apart from cosmesis (8). Therefore, we should balance potential advantages with potential additional risks due to increased technical challenges as the invasiveness of procedures further decreases.

Despite the specific techniques chosen by Chen and colleagues, as well as variations by peers around the world, selection remains a matter of surgical skills and preference while keeping in mind the patient-specific characteristics while simultaneously considering the readily available scientific evidence. In general, minimally invasive approaches such as VATS and laparoscopy demonstrate superior results to open procedures and technical innovations undoubtedly will further enable less invasive surgery, also for complex resections as these. Time will tell how far these techniques, including for example scarless surgery through endoscopic approaches, will take root and become future standard care.

\section{Acknowledgments}

Funding: None.

\section{Footnote}

Provenance and Peer Review: This article was commissioned by the editorial office, Translational Lung Cancer Research. The article did not undergo external peer review.

Conflicts of Interest: All authors have completed the ICMJE uniform disclosure form (available at https://dx.doi. org/10.21037/tlcr-21-766). The authors have no conflicts of interest to declare.

Ethical Statement: The authors are accountable for all aspects of the work in ensuring that questions related to the accuracy or integrity of any part of the work are appropriately investigated and resolved.

Open Access Statement: This is an Open Access article distributed in accordance with the Creative Commons Attribution-NonCommercial-NoDerivs 4.0 International License (CC BY-NC-ND 4.0), which permits the non- commercial replication and distribution of the article with the strict proviso that no changes or edits are made and the original work is properly cited (including links to both the formal publication through the relevant DOI and the license). See: https://creativecommons.org/licenses/by-nc-nd/4.0/.

\section{References}

1. Chen J, Ang KL, Wang C, et al. Minimally invasive carinal reconstruction using bronchial flap and omental flap reinforcement. Ann Thorac Surg 2021;29;S00034975(21)01088-2. [Epub ahead of print]. doi: 10.1016/ j.athoracsur.2021.06.014.

2. Whitson BA, Groth SS, Duval SJ et al. Surgery for earlystage non-small cell lung cancer: a systematic review of the video-assisted thoracoscopic surgery versus thoracotomy approaches to lobectomy. Ann Thorac Surg 2008;86:200816; discussion 2016-8.

3. Lim EKS, Batchelor TJP, Dunning J et al. Videoassisted thoracoscopic versus open lobectomy in patients with early-stage lung cancer: One-year results from a randomized controlled trial (VIOLET). J Clin Oncol 2021;39:8504-.

4. Ramos R, Masuet C, Gossot D. Lobectomy for early-stage lung carcinoma: a cost analysis of full thoracoscopy versus posterolateral thoracotomy. Surg Endosc 2012;26:431-7.

5. Zhang $Z$, Zhang $\mathrm{Y}$, Feng $\mathrm{H}$ et al. Is video-assisted thoracic surgery lobectomy better than thoracotomy for early-stage non-small-cell lung cancer? A systematic review and metaanalysis. Eur J Cardiothorac Surg 2013;44:407-14.

6. Shrager JB, Wain JC, Wright CD et al. Omentum is highly effective in the management of complex cardiothoracic surgical problems. J Thorac Cardiovasc Surg 2003;125:526-32.

7. Harris CG, James RS, Tian DH et al. Systematic review and meta-analysis of uniportal versus multiportal videoassisted thoracoscopic lobectomy for lung cancer. Ann Cardiothorac Surg 2016;5:76-84.

8. Evers L, Bouvy N, Branje D et al. Single-incision laparoscopic cholecystectomy versus conventional fourport laparoscopic cholecystectomy: a systematic review and meta-analysis. Surg Endosc 2017;31:3437-48.

Cite this article as: Daemen JHT, Vissers YLJ, Hulsewé KWE, de Loos ER. Editorial commentary: a journey towards least invasive thoracic surgery? Transl Lung Cancer Res 2021;10(10):4027-4028. doi: 10.21037/tlcr-21-766 